\title{
An analytical study of child labour in the agriculture sector of the rural areas of central Punjab, Pakistan
}

\author{
Shabbir Ahmad ${ }^{1}$, Wu Huifang ${ }^{*}$, Saira Akhtar ${ }^{2}$, Sobia Maqsood ${ }^{2}$ and Shakeel Imran ${ }^{3}$ \\ ${ }^{1}$ College of Humanities and Development Studies, China Agricultural University, No. 17, Qinghua Donglu, Haidian District, \\ 100083, Beijing P. R. China. \\ ${ }^{2}$ Department of Rural Sociology, University of Agriculture, Faisalabad, Punjab, Pakistan. \\ ${ }^{3}$ University of Agriculture, Faisalabad, Sub Campus Burewala, Punjab, Pakistan.
}

\begin{abstract}
Child labour is a critical concern of many developing countries in the South Asian wing, including India, Pakistan and Bangladesh. There is an obvious lack of information regarding child labour among the remote rural areas of Pakistan. Due to poor and critical economic circumstances, people are forced to send their children to work in agricultural farms, factories, mills (processing units) and brick kilns. The major factors behind child labour include generational poverty, high illiteracy ratio among the parents, unemployment, large family sizes, feudalism and flexibility in the existing child labour laws. The present research study was conducted in the rural areas of Faisalabad district which is located in the central region of the Punjab Province of Pakistan. Multistage sampling technique was utilised through the course of this entire study. At the first stage, one tehsil (Jaranwala) was selected randomly from the selected district. At the second stage, three Union Councils were selected randomly from the selected tehsil. At the third stage, two villages were selected from each Union Council (total 6 villages) by using stratified random sampling technique. Furthermore, at the fourth stage, 30 children were selected as respondents (180 in total) by convenient sampling from the selected villages. A comprehensive and well-structured interview schedule was prepared, keeping in view the objectives of this research study, and it was personally administered on the respondents in the form of face-to-face interview. This research study found that $71.7 \%$ of the respondents were males, $47.2 \%$ belonged to the age group (11-15) years, $40.6 \%$ lived in the joint family system and $50.0 \%$ were illiterate. Furthermore, $53.3 \%, 49.4 \%, 46.1 \%$, $28.3 \%, 17.2 \%$, and $14.4 \%$ of the respondents were involved in land preparation, weeding, seeding/sowing, irrigation, water management, and fertilizing in the agricultural sector, respectively. Most of the respondents (51.1\%) claimed that they were working to support their respective families and $50.0 \%$ of the respondents told that they were punished and verbally abused by their employers. The study concluded that irrespective of the fact that the government of Pakistan
\end{abstract}

is working for the upliftment of the children in the rural areas, the trend of child labour is rising gradually due to the poor economic conditions of the rural families. As long as the economic condition of the rural people is not strengthened, the children will continue to work in the agricultural sector as child labourers, and they will continue to be exploited by the feudal lords in the rural areas and industrialists in the urban settlements.

Keywords: Child labour, wage discrimination, social injustice, illiteracy, unemployment, joint family system, central Punjab, Pakistan.

\section{INTRODUCTION}

Child labour is one of the major concerns of developing countries around the globe, but not everywhere in the same magnitude (Bass, 2004). Child labour is still going on in the various fields in spite of the fact that legislation which discourages child labour is present (Khan, 2014). Child labour was identified as a problem in 1990s by the developed countries, who themselves were extensively involved in child labour in the past. Later on, it was regarded as a severe violation of human rights, and different NGOs \& humanitarian organisations raised their voice against child labour (Fyfe, 2004). Furthermore, child labour contributes to unemployment among the young labour force due to the wage differences (ILO, 2006a). In the developing countries, children and women are underpaid as compared to the young male labour force. That is why the former are preferred over the young male labour force in agricultural fields, at brick kilns, in workshops, in various mills and factories and in hotels and restaurants. It has been estimated that $75 \%$ ( 1.1 billion) of the poor who earn less than one dollar per day, live in the rural areas and depend directly or

"Corresponding author (wuhf@cau.edu.cn; (iD https://orcid.org/0000-0002-7069-6045) 
indirectly on agriculture for their livelihood (PinstrupAndersen \& Pandya-lorch, 2001; Okunmadewa, 2001; ILO, 2006a; Etim et al. 2009; Etim \& Udofia, 2013). Due to this poverty, about 317 million children are forced to work at different places to meet the expenses of their families, leaving their schools (ILO, 2006a). It is ironical that in spite of the efforts of NGOs, extensive campaign on the mass media, legislation on the part of the government against this social evil and funding provided by UNICEF, child labour is increasing in developing countries like India, Bangladesh, Pakistan, and Afghanistan; contributing to half of total child labour around the world (Fyfe, 2004).

The estimates of Child Labour Survey of Pakistan conducted by the International Labour Organization reveals that in $2008,8.3 \%$ (3.3 million) out of 40 million children, in the 5-16 year age cluster, were full time or part time workers in several informal and formal areas in almost all the provinces of Pakistan (ILO, 2008). Maple Croft's 2014 Child Labour Index has ranked 196 countries around the globe and pointed out that 83 countries including Pakistan, where the problem of child labour is the greatest, have been ranked as "extreme risk". In the agricultural sector of Pakistan, about $60 \%$ of the young child labourers are working to earn their living on minor wages facing unsuitable working environment (Pakistan, National Rural Support Programme, n. d). In the different segments of agriculture such as sowing, plantating, harvesting, aquaculture, forestry, livestock, dairy, poultry and fisheries, about 129 million boys and girls, aged 5-17 years, are working without the provision of any safety measures such as gloves, masks and other paraphernalia (ILO, 2010). Child labourers often face sexual harassment, psychological disorders, malnutrition, and become victims of viral diseases. Around 59\% (or 70 million) of all children aged 5-17 years are in the farming industry (Mendelievich, 1979). Child labour isolates children from the social panorama, diminishing the chances of their healthy growth by involving them in work from dawn to dusk, which is very disastrous since it can lead them to deviant behavior (Akarro \& Mtweve, 2011). There are countless factors which contribute to child labour in a developing country like Pakistan, such as absolute poverty, faulty education system, fatalism, the traditional professionalism, forced and bounded labour in some of the provinces such as Sindh \& Baluchistan, agrarian-based economy etc. (United Republic of Tanzania, National Bureau of Statistics, 2007). In spite of the fact that comprehensive legislation against child labour is present in Pakistan, the facts and figures are contrary to the situation. Approximately, 20 million school going children are not attending schools, and almost 10 million children are engaged in child labour in different sectors, particularly in the agriculture field (Takkar, 2018).

The key objectives of this research were to explore the major factors which force the children to work in the agriculture sector; to find out the problems of the agricultural child labourers; and finally, to suggest some measures to minimise child labour in the agricultural sector. The paper is divided into the following sections: "Introduction" includes general situation of child labour and the efforts of the government to mitigate it from every sphere of life; "Material and methods" section tries to brief the reader about the geographical area, research design, sampling method, tool of data collection and software used for analysis; "Results and discussion" section describes in detail the results of the survey conducted; the final section provides conclusions along with the recommendations for the future course of action.

\section{Significance of the study}

The government of Pakistan has made comprehensive legislation at the provincial and national level to mitigate child labour. However, children in poverty still can be seen working in the fields, mills, brick kilns, workshops, tea stalls, restaurants and at many other places, where they are provided with unhygienic work environments, minor wages, long duty hours and sometimes, sexual exploitation. The government did not take notice because most of the institutions where child labour is practiced are under the control of the politicians. Due to poor economic conditions, families are forced to send their children to work instead of sending them to schools, leaving the country deprived of the skilled labour force and plunging deep down in the vicious circle of poverty. This type of research studies are an attempt to shake the slumbering governments of the third world countries out of their stupefaction. It must be brought to the notice of the governments of the developing countries that if they fail to prepare their children with best of the available skills, they will not be able to stand in the line of the developed and civilised nations around the globe.

\section{Theoretical framework of the study}

The theory of exploitation of labour put forward by Karl Marx (1847) can be contextualised to describe the existing condition of child labour in Pakistan. The workers, particularly women and children, are exploited by the feudal lords in the rural areas and industrialists in the urban settlements (Rogers \& Swinnerton, 2008; Ferguson \& Steiner, 2016). Poor economic circumstances forced them to sell their labour power to the capitalists for less than the full value of the commodities they produce 
with their labour (Cohen, 1978; Sample, 2003; Rogers \& Swinnerton, 2008). Other exploitation theorists such as Hillel Steiner, Robert Goodin and Matt Zwolinski argued similar to Marx that insufficient economic resources available to the parents compel them to send their children to work (Steiner, 1984; 1987; 2013; Goodin, 1987; Zwolinski, 2012). The agricultural sector of Pakistan has become a "sweatshop", where the un-skilled child labourers are subject to low wages, long working hours and unsafe working conditions (Arnold \& Bowie, 2003; Powell \& Zwolinski, 2012). The child labourers, both boys and girls, sometimes in persuasion of higher earnings for their families, plunge down to worst forms of child labour and undergo abject exploitation at the work place (Rialp, 1993; Mullings, 1999; Kempadoo, 1999; Narayan, 2000; Dessy \& Pallage, 2005). In Narayan (2000), it is also evident that choosing the worst forms of child labour for one's child is not without moral pain and would never have happened in the absence of poverty and social inequality in the rustic society.

Economic theories such as neoliberalism can also be applied to contextualise child labour, with few exceptions, based on some shared premises. First, that child labour is socially undesirable and its reduction is a worthy goal. Second, that there are other, more desirable, activities in which a child can engage, namely, school attendance and leisure. Third, that the child labour decision is the prerogative not of the child but of the parent. However, the parent is motivated not by narrow self-interest but by a benevolent and rational outlook which considers the welfare of the whole household, including that of the child (Jafarey \& Lahiri, 2001). In this context, the parent shares in the undesirable consequences of child labour, through the introduction of a psychological cost of children working upon the request of the parents. If parents dislike child labour, then the decision to impose it upon their children must be based on the economic conditions faced by the household. It is fair to say that a single factor has been emphasised in all economic explanations of child labour: abject poverty. However, precisely in what fashion does poverty influence child labour? This is where differences arise (Jafarey \& Lahiri, 2001). Basu (1999), Ranjan (1999), Dessy (2000), Emerson \& De Souza (2000), and Grootaert (1998) have linked child labour with poverty among the parents. They claimed that child labour is fundamentally a by-product of poverty, strongly suggesting that policy should focus on economic development and increasing income (Nardinelli, 1990). Although the poverty/child-labor link may seem obvious, Baland \& Robinson (2000) formalise this idea, thus helping to isolate the precise nature of the mechanism. They take as a point of departure that all families make child-labour decisions to maximise the present discounted value of the household's income
(Simler et al., 2004). An empirically testable hypothesis of Basu \& Van's (1998) model is that child labour arises if adult household income falls below some benchmark level. A test of this hypothesis was attempted by Ray (2000) for Pakistan, using "poverty line" as the benchmark income level. For Pakistan, Ray used data from the Pakistan Integrated Household Survey of 1991 (PIHS). He found statistically compelling evidence that when a

"Pakistani household falls into poverty... it significantly and substantially increases its children's involvement in outside, paid employment by about 500 hours annually for each child" (Ray, 2000).

Similar findings have been reported by Addison et al. (1997) for Ghana and Pakistan, Bhalotra \& Heady (1998) for Pakistan, and Ray (2000) for India. Consequently, it induces the rate of poor household parents sending their children to schools rather than to work. Moreover, when a family's income reaches a certain level, parents are more likely to withdraw their children from the labour force (Jafarey \& Lahiri, 2002; Rajan, 2001). It should be considered that in developing countries like Pakistan, child labour may come under dual pressure from both income and substitution effects during the globalisation process (Dagdemir \& Acaroglu, 2010; Reeve, 1987; Castillo \& Salem, 2016).

\section{Operational definitions and conceptual framework of the study:}

Some of the major concepts which are operationalised to comprehend the phenomena are discussed below. The conceptual framework of the study is depicted by Figure 1 .

\section{Agriculture}

The most appropriate definition of agriculture which is used in this study is: the art or practice of farming which include in its range, cultivation of the soil for the growing of crops and the rearing of livestock to provide food, wool and other products by the extensive labour of the farming class. The farmers' agricultural activities are categorised as: land preparation, seed preparation, sowing, irrigation, application of fertilizers, spraying the crops, weeding, harvesting, cotton picking along with implanting rice saplings, taking care of livestock including feeding, milking and cleaning.

\section{Child labour}

The definition of child labor which has been used in this study is: the act of involving children (male or female), who are under eighteen years of age, with work in fields, 
mills, factories and at any other place instead of going to school, supporting their respective families from the economic point of view, against the directions of the government. In this research study, the term child labour has been used for the children who are involved in the farming sectors irrespective of the fact that child labour is going on in many other sectors in the capitalistic-based economy of Pakistan. Children are working in the fields on minor wages, without wages, and forcibly (in some of the rural areas of Punjab and Sindh).

\section{Income}

Income is defined as: the money an individual earns from all the resources per month or per year. As the article discusses rural areas and the agricultural panorama, usually, whatever the farming community earns from their crops, livestock, poultry and fish farming can be attributed as their income. In this research study, people are categorised keeping in view the amount of money they earn (monthly, in Pakistani rupees [PKR]). The following categories have been made: Up to PKR 10,000 per month, 10,001-12,000 PKR per month, and 12,001 PKR per month and above. It must be kept in mind that it is not the income of the children who are labouring in the fields, but it is the income of their parents.

\section{Age}

The most suitable definition of age which was utilised in this study: it is the particular stage in someone's life when he became qualified to undertake certain personal and civil rights and responsibilities. In Pakistan, this definition applies to a person who attains the age of eighteen years. In the present study, the following categories were used to identify the age of the respondents: up to 5 years, 6 to 10 years, and 10 years and above. All these categories allude to the under-age children who are not legally permitted to be engaged in any types of work anywhere except getting education.

\section{Family}

Family is the aggregation of people who are tied to one another via blood relations, living at the same place, sharing the sorrows, happiness, and extending economical support to the other family members. Family is usually responsible for the provision of food, shelter, clothing, education, financial security and recreation. The rural families are unable to provide all the above-mentioned facilities to the children due to the unavailability of economic resources and are forced to send their children to work. In the present study, family is categorised into the following groups: nuclear family, joint family, and extended family. Most of the rural families live in joint family system and the concept of extended family is gradually fading away due to the fragmentation of agricultural land generation after generation and due to migration of people to the urban ares in search of jobs.

\section{Rural area}

The concept of rural area is conceptualised in this research study as: the area where most of the people are engaged in agriculture, livestock, poultry and fish farming, where there is absence of the basic facilities such as education, health and means of sustenance. The people usually have a rigid, traditional and orthodox view about life. Where there is the dominance of men over the family issues and women have no access to resources and are generally excluded from the decision-making process.

\section{REVIEW OF LITERATURE}

The determinants of child labour have been studied in Asia (Muhammad, 1993; Mukhopadhyay, 1994; Sharif, 1994; DeGraff et al., 1993; Cochrane et al.,1990); Africa (Togunde \& Weber, 2007; Ahmed et al., 2007; Togunde \& Carter, 2006; Togunde \& Richardson, 2006; Grier, 2004; Canagarajah \& Nielsen, 2001; Grootaert \& Patrinos, 1999); and in Latin America (Emerson \& De Souza, 2003; Levison et al., 2001; Binder \& Scrogin 1999; Patrinos \& Psacharopoulos, 1997). All these studies have found that poverty was the most prominent factor responsible for child labour. Moreover, there are 98 million child labourers (majority 77.7 million in Asia and Pacific) who are working in the agriculture sector, accounting for $58.6 \%$ of all those in child labour worldwide (ILO-IPEC, 2013). Basu \& Van (1998), Maitra \& Ray (2002), Pakistan, Ministry of Labour, Manpower \& Overseas Pakistanis, ILO \& IPEC (1996) and Ersado (2005) concluded that the children are forced to perform in the agriculture sector as child labourers because their families are not able to provide them the basic needs of life such as food, health, education and shelter.

Moreover, Moehling (1999), Ray (2002) and Kis-Katos \& Gunther (2005) also concluded in their research studies that poverty was the major reason of the involvement of children in child labour in the agricultural sector. The studies conducted by Crowley \& Johnson (2004), ILO (2005), Human Rights Watch (2002), Bangladesh Bureau of Statistics \& ILO (20022003), ILO-IPEC (2011), FAO (2015), Diallo et al. (2013) and Ortiz-Ospina \& Roser (2016) concluded that children of 5-17 and 5-14 years of age, respectively, are found to be involved in hazardous agricultural child labour in the developing countries around the world out of extreme poverty. Nasarullah et al. (2013) and Cigno et al. (2002) pointed out that globalisation is responsible for child labour in the agriculture sector, especially in 


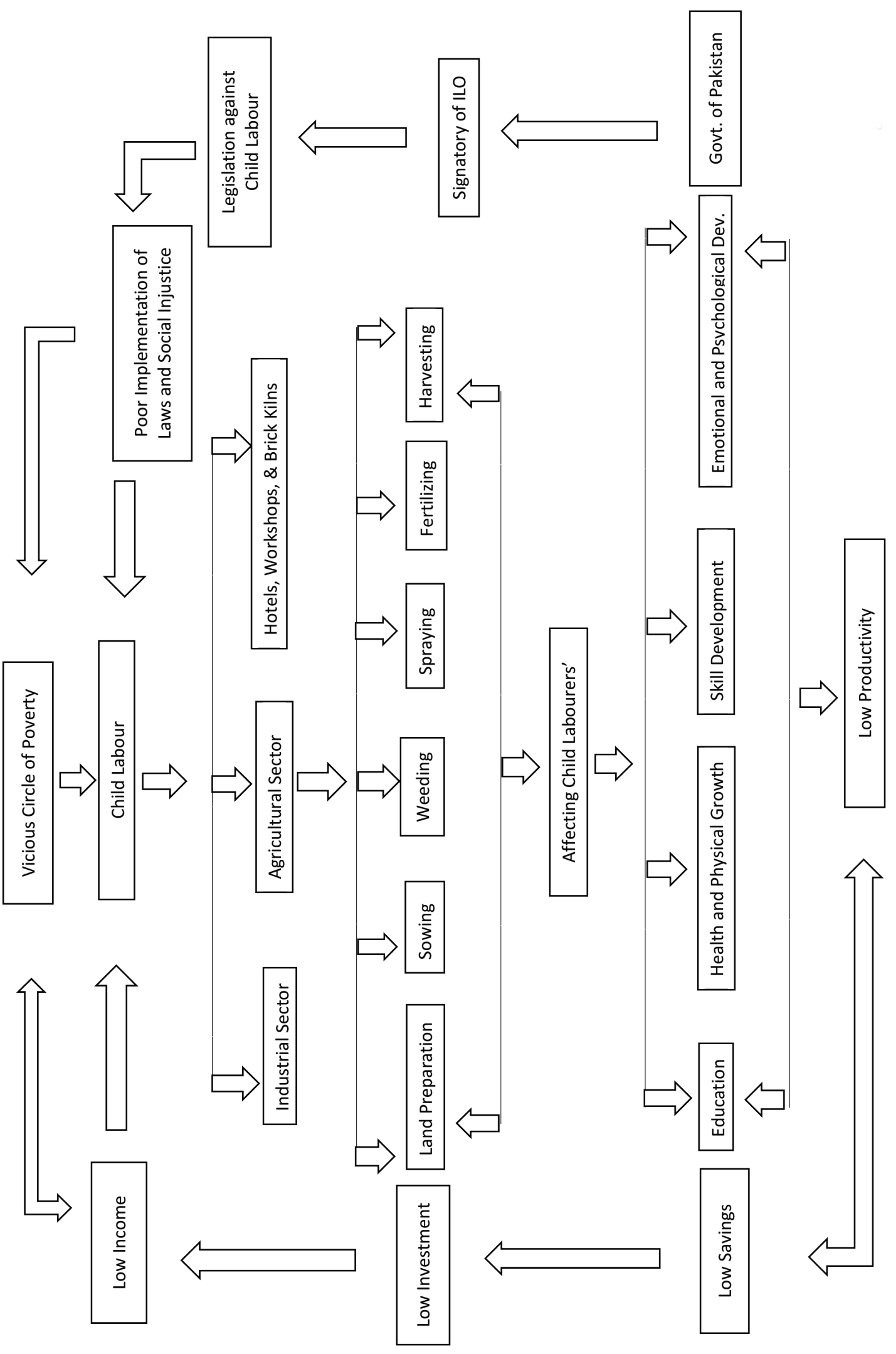


the developing countries around the world. They were of the opinion that globalisation is responsible for the closure of small-scale industries in the rural areas of the developing countries, leading thousands of families rendered unemployed. The children of the labourers have been forced into child labour and are caught in the web of economic exploitation. Finally, White (1996) was of the view that globalisation has bestowed a definite consciousness to the child labourers of their intergenerational poverty because of the massive flow of information regarding the presence of modern life style and the resulting desire to adopt such type of life style has rendered them as working machines.

\section{MATERIALS AND METHODS}

The present study was a cross sectional quantitative study which was conducted in the rural areas of Punjab, Pakistan. The Punjab province is generally divided into three geographical regions; upper Punjab (which is an arid area), central Punjab (rich green area) and southern Punjab (mostly consists of desert areas). Central Punjab was selected because it is the only rich green and fertile area where there is massive agricultural activity going on in the rural areas. Furthermore, multistage sampling techniques were employed during the course of this research study. At the first stage, one district (Faisalabad) was selected from central Punjab by the utilisation of simple random sampling technique. There are six tehsils (a tehsil is an administrative subdivision of a district) in Faisalabad district: Faisalabad City, Faisalabad Sadar, Chak Jhumra, Jaranwala, Tandlianwala and Samundri. At the second stage, one tehsil (Jaranwala) was chosen from the chosen district randomly. At the third stage, three Union Councils were selected by using stratified random sampling technique. At the fourth stage, two villages were selected from each Union Council. At the fifth stage, thirty respondents were selected from each village by convenient sampling (180 in total). A well-structured questionnaire was used as a data collection tool containing close-ended, Likert Scale, open-ended and contingency questions. The first part of the questionnaire consisted of the demography-related questions, the second part tried exploring the factors which involve children in child labour and the third part tried to investigate the problems working children face in the agriculture sectors. The last part of the questionnaire contained a set of open-ended questions about future policy formulation. The questionnaire was administered personally by the researcher in the form of face-to-face interview. The collected data was analysed using SPSS software. To check the association between the variables, Chi square test was utilised, and Gamma test was administered to check the direction of the association of the variables (either positive or negative), at $5 \%$ level of significance (Table 1).

\section{RESULTS AND DISCUSSION}

The univariate analysis of the data involves the discussion of a single variable involved in the research study. It does not seek to identify the causal relationship between the variables. It helps to find patterns that exist within the data. In this section, the demographic variables such as gender, age, schooling, family composition, family income, needs of the working children, reasons behind their involvement in child labour, nature of working and the problems of the working children has been analysed and the results are compared with other studies in order to assess the situation of child labour not only in Pakistan but around the globe as well.

Table 2 shows the distribution of the respondents according to different demographic characteristics. According to gender, $71.7 \%$ and $28.3 \%$ of the respondents were males and females, respectively. The males often work in the fields and the females are engaged in the maintenance of livestock and other domestic chores. That is why the percentage of male child labourers working in the fields is higher than that of the female child labourers. It has been reported by ILO (2010) that male child labour is higher than female child labour. The results of this study are very much in line with the findings of ILO. The analysis of the age of children revealed that often 11-15 years old $(47.2 \%)$ children are involved in child labour. The highest occurence of total number of family members of children

Table 1: Distribution of the respondents of the selected sample

\begin{tabular}{lrrrrrr}
\hline Name of tehsil & $\begin{array}{r}\text { Total No. of } \\
\text { Union Councils }\end{array}$ & $\begin{array}{r}\text { Sample of Union } \\
\text { Councils drawn }\end{array}$ & $\begin{array}{r}\text { No. of villages } \\
\text { selected }\end{array}$ & $\begin{array}{r}\text { Sample of } \\
\text { villages drawn }\end{array}$ & $\begin{array}{r}\text { Sample of } \\
\text { respondents from } \\
\text { each village }\end{array}$ & $\begin{array}{r}\text { Size of the total } \\
\text { sample }\end{array}$ \\
\hline Jaranwala & 57 & 3 & 25 & 6 & 30 & 180 \\
\hline
\end{tabular}


Table 2: Socio-economic characteristics of the respondents *

\begin{tabular}{|c|c|c|c|}
\hline Statement & Response & $\begin{array}{r}\text { Frequency } \\
\mathrm{N}=180\end{array}$ & $\%$ \\
\hline \multirow[t]{2}{*}{ Gender } & Male & 129 & 71.7 \\
\hline & Female & 51 & 28.3 \\
\hline \multirow[t]{3}{*}{ Age groups (years) } & $5-10$ & 18 & 10.0 \\
\hline & $11-15$ & 85 & 47.2 \\
\hline & $16 \&$ above & 77 & 42.8 \\
\hline \multirow[t]{3}{*}{ Total family members } & Up to 5 & 29 & 16.1 \\
\hline & $6-10$ & 103 & 57.2 \\
\hline & $10 \&$ above & 48 & 26.7 \\
\hline \multirow[t]{2}{*}{ Ever attended school } & Yes & 99 & 55.0 \\
\hline & No & 81 & 45,0 \\
\hline \multirow[t]{4}{*}{ Educational level } & Illiterate & 81 & 45.0 \\
\hline & Below primary & 46 & 25.6 \\
\hline & Middle & 48 & 26.7 \\
\hline & Above middle & 5 & 2.8 \\
\hline \multirow[t]{3}{*}{ Family structure } & Nuclear & 60 & 33.3 \\
\hline & Joint family structure & 73 & 40.6 \\
\hline & Extended family & 47 & 26.1 \\
\hline \multirow{3}{*}{$\begin{array}{l}\text { Family income } \\
\text { (PKR; monthly) }\end{array}$} & Up to 1000 & 35 & 19.4 \\
\hline & $10001-12000$ & 88 & 48.9 \\
\hline & Above 12001 & 57 & 31.7 \\
\hline \multirow[t]{4}{*}{ Tenancy status } & Owner & 17 & 9.4 \\
\hline & Tenant & 42 & 23.3 \\
\hline & Owner-cum-tenant & 50 & 27.8 \\
\hline & No land & 71 & 39.4 \\
\hline
\end{tabular}

"Source: Survey data

involved in child labour in the agriculture sectors is 6-10. The higher percentage $(57.2 \%)$ is enough to describe the living standard of the rural families, and the children are forced to work not only in the agriculture sector but in the mills and industries too. The total monthly income of the families earned from all resources is between the range of 10,001 to $12,000 \mathrm{PKR}$ (48.9\%), which is enough to support the fact mentioned above regarding the child labour. The literacy level among the children who work in the agriculture sector as child labourers is very low and data shows that majority of the respondents are illiterate $(45.0 \%)$. The higher illiteracy among the children is due to the low income of the parents and the children being forced to work to sustain their family income. Even though the government of Pakistan is providing free education along with free books and uniforms, the rural families are still not sending their male children to school. The government has started a UPE (Universal Primary Education) program but no considerable success is witnessed. ILO-IPEC (2014) stated that mostly the children are out of school because of poverty and large family size. Especially, girls do not attend school due to male dominance and the traditional family patterns which discourage girls' education. In the rural areas, the boys are preferred for education because they are considered as to support the family and the girls to perform domestic chores. If the socio-economic characteristics of 
the respondents are deeply analysed, one will notice that majority of the children (40.6\%) live in joint family systems (a family in which there are grandparents, uncles, aunties and lot of cousins), majority of them (60.6\%) have their own land, and majority of them (27.8\%) belong to families which are owner-cum tenants. The results of this study are very much in line with the findings of Kazmi (2015) who concluded that $75.5 \%$ of the respondents belonged to the rural areas, $32.3 \%$ belonged to the age group 11-14 years, $52.3 \%$ were males, $23.2 \%$ were illiterate, $52.6 \%$ were engaged in the child labour in the rural areas, and $64.4 \%$ of the respondents earned less than 100 rupees per day.

Table 3 presents data on children who are working in the pre-harvesting agricultural activities in the agricultural sector. Their activities range from sowing to harvesting of the crops. The table reveals that $54.4 \%$ of the respondents said that they were working "to a great extent" in land preparation activities. This sounds dangerous for the children to deal with mechanical tools which are sharp enough to injure them (Anker, 2000). About half of the child labourers $(50.0 \%)$ responded that they had been involved in weeding of cotton, wheat, potatoes and other crops "to a great extent", even in harsh weather without any precautionary measures. $51.2 \%$ of the respondents said that they worked in seed sowing using drills and other risky instruments "to a great extent". $47.3 \%$ of the respondents told the interviewer that they managed irrigation of the crops "to a great extent". They even managed irrigation at night without the availability of precautionary measures such as long boots, medical kits, and other paraphernalia to save themselves from snake bite. $52.8 \%$ of the respondents replied that they worked as child labourers in fertilizing the crops "to a great extent". A research study was conducted by Pakistan, National Rural Support Program (n. d) and the results related to land preparation, sowing, fertilizing, watering, spraying, weeding, rigging, picking and plant cutting have been summarised in Figure 2. It shows that extensive child labour is going on in the agriculture sector which has hazardous effects on the social, religious and educational upbringing of the male and female children. The children are at risk while using agricultural tools such as thresher, ploughs, etc. Risk of injuries while irrigation due to snake bite at night is quite common among the male children.

Table 3: Child labour in pre-harvesting agricultural activities *

\begin{tabular}{lcccccc}
\hline \multirow{2}{*}{$\begin{array}{l}\text { Pre-harvesting } \\
\text { agricultural activities }\end{array}$} & \multicolumn{2}{c}{ To a great extent } & \multicolumn{2}{c}{ To some extent } & \multicolumn{2}{c}{ Not at all } \\
\cline { 2 - 7 } & $\mathrm{f}$ & $\%$ & $\mathrm{f}$ & $\%$ & $\mathrm{f}$ & $\%$ \\
\hline Land preparation & 98 & 54.4 & 39 & 21.7 & 43 & 23.9 \\
Weeding & 90 & 50.0 & 57 & 31.7 & 33 & 18.3 \\
Seeding/Sowing & 92 & 51.2 & 66 & 36.7 & 22 & 12.3 \\
Irrigation & 85 & 47.3 & 70 & 38.9 & 25 & 13.9 \\
Water management & 75 & 41.7 & 80 & 44.5 & 25 & 13.9 \\
Fertilizing & 95 & 52.8 & 50 & 27.8 & 35 & 19.4 \\
\hline
\end{tabular}

"Source: Survey data

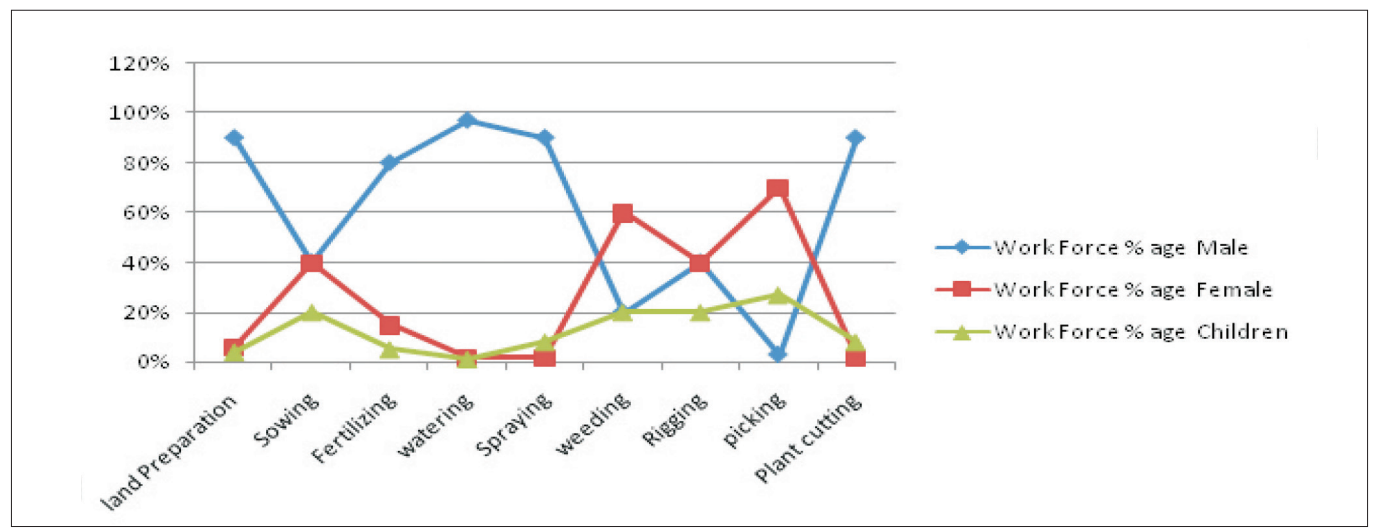

Figure 2: Child labour in cotton seed farming, Pakistan

Source: Pakistan, National Rural Support Program (n. d) 
Often precautionary measures are not adopted while working in the fields. It is up to the labourers to arrange all the precautionary paraphernalia while working (ILO, 2013).

Table 4 illustrates the weak financial condition of the households which forces children to work as child labourers in the fields. The contents of Table 4 show that $58.9 \%$ of the respondents told in affirmation that they had been working in the agricultural sector because it was their family profession. More than half (66.7\%) of the respondents affirmed that they had to work in the fields to support the basic needs of the family. 33.4\% responded that they are working in the agricultural sector willingly. $61.7 \%$ of the respondents claimed that their parents direct them to work as child labourers in the fields to support the household expenses. The earlyage work badly affects the cognitive development of the children as well as their preferences for the future orientations (Lee \& Jackson, 2017), because they never achieve the status of skilled working machinery and do not have many opportunities other than working as child labourers. The results of this research study are very much in line with the study conducted by ILO (2005). Child labour, irrespective of the type of reasons involved, affect the health, education and mental upbringing of the children to a great extent. The results of this study are also very much in line with ILO (2015), Faria (2010), Lana (2014) and Silvers (1996) which reported that poverty, limited access to quality education, inadequate

Table 4: Major reasons behind child labour *

\begin{tabular}{|c|c|c|c|c|}
\hline \multirow{3}{*}{$\begin{array}{l}\text { Reasons of involvement in } \\
\text { child labour }\end{array}$} & \multicolumn{2}{|c|}{ Yes } & \multicolumn{2}{|c|}{ No } \\
\hline & Frequency & $\%$ & Frequency & $\%$ \\
\hline & $\mathrm{N}=180$ & & $\mathrm{~N}=180$ & \\
\hline Family profession & 106 & 58.9 & 74 & 41.2 \\
\hline To support the family & 120 & 66.7 & 60 & 33.4 \\
\hline Personal interest & 60 & 33.4 & 120 & 66.7 \\
\hline $\begin{array}{l}\text { Family canot afford } \\
\text { educational expenses }\end{array}$ & 133 & 73.9 & 47 & 26.2 \\
\hline $\begin{array}{l}\text { Head of family determined } \\
\text { that you should work }\end{array}$ & 111 & 61.7 & 69 & 38.3 \\
\hline
\end{tabular}

Table 5: Major economic factors which force the children to get involved in child labour *

\begin{tabular}{lcccc}
\hline Needs behind child labour & \multicolumn{2}{c}{ Yes } & \multicolumn{2}{c}{ No } \\
\cline { 2 - 5 } & Frequency & $\%$ & Nrequency & $\%$ \\
& $\mathrm{~N}=180$ & & 57 & 31.7 \\
\hline Education ${ }^{1}$ & 123 & 68.3 & 66 & 36.7 \\
Security & 114 & 63.3 & 82 & 45.6 \\
Increase salary & 98 & 54.4 & 84 & 46.7 \\
Safe working condition & 96 & 53.3 & 63 & 35.0 \\
Shelter & 117 & 65.0 & 48 & 26.7 \\
Water supply & 132 & 73.3 & 72 & 40.0 \\
Nutrition & 108 & 60.0 & & \\
\hline
\end{tabular}

"Source: Survey data 
agricultural technology, cheap labour and lack of adult labour are the main reasons behind the involvement of rural children in child labour in the agriculture sector (Table 5).

Child labour is not only in the agricultural sector, but it is present in the domestic and industrial sectors as well. There are needs of the child labourers as well as their families behind this dark aspect. More than half (68.3\%) of the respondents affirmed that they are working to support their educational expenses, as their parents are not able to support them in their education due to economic problems. A clear majority of $31.7 \%$ responded "No", they did not need education. The obvious reason behind this reply in negation is the factor of unemployment among the educated people with degrees/diplomas. This attitude is spreading pessimism among the parents of the rural families. About $63.3 \%$ of the respondents responded "Yes", they needed security while $36.7 \%$ responded "No", they did not need security. More than half $(54.4 \%)$ of the respondents said "Yes", they had a need of increased salary, while 45.6\% said "No", they do not need an increased salary. More than half (53.3\%) of the respondents said "Yes", they had a need of safe working conditions, while $46.7 \%$ responded in negation, saying that they did not want to have safe working conditions.

Regarding shelter, $65.0 \%$ of the child laborers told that they needed shelter while working in harsh conditions, while $35.0 \%$ replied in negation about shelter. $73.3 \%$ of the respondents responded in affirmation that they had a need of drinking water supply ${ }^{2}$, while $26.7 \%$ responded in negation about the need of water supply. Around $60.0 \%$ of the respondents said "Yes", they need nutrition and $26.7 \%$ responded in negation about needing nutrition. The working children responded about the need of education, increase in salary, safe working conditions, security, shelter and about the availability of nutritious food. However, the socio-economic conditions of the families of the working children are not quite satisfactory because mostly they are living in rented houses, have more than six children, have to entirely depend on labour which is seasonal in its nature, and other social issues.

Table 6 shows the distribution of the respondents according to punishments they received while working as child labourers in the agriculture sector. The child labourers often received mental and physical torture along with salary deduction from the zamindars, landlords and the stewards (Munshi ${ }^{3}$ ). The data collected from the respondents reveal that $13.9 \%$ of the respondents faced mental torture. $30.5 \%$ of them said that they received verbal, mental and even physical punishment from their respective owners. The obvious reason is that often the rural elite consider the poor people as their personal commodity. In the villages of Pakistan, abusing, taking personal errands and even giving physical punishment to the "Kamins" is considered a sign of respect. In this way, they try to maintain their hold on the rural people. $19.0 \%$ of the respondents claimed that they did not receive any type of punishment from their employers. The children who work at the workshops, motor garages, at the shops of motor cycle mechanics, in factories and mills, received severe type of physical and verbal punishment from their masters. They are mercilessly beaten by iron tools and plastic pipes.

"One of the respondents told that he had been an apprentice at a turner shop. The duty hours were very long, and the working place was like a dungeon. The master, who happened to be the owner, used to beat him on minor pretexts. He several times complained to his parents, but they remained silent. He left the shop, and now he is

Table 6: Type of punishments the child labourers are subjected to*

\begin{tabular}{lrr}
\hline Type of punishment & Frequency & $\%$ \\
& $\mathrm{~N}=180$ & 13.9 \\
\hline Mental torture & 25 & 27.7 \\
Physical torture & 50 & 30.5 \\
Physical and mental torture & 55 & 8.3 \\
Salary deduction & 15 & 8.8 \\
Salary deduction and physical torture & 16 & 10.5 \\
Did not receive any punishment & 19 & 100.0 \\
Total & 180 & \\
\hline
\end{tabular}

"Source: Survey data 
working at the farm with minor difference in the attitude of the owners".

Their parents know everything but their lips are sealed because they are forced by the absence of resources and are unable to nourish their children. The findings of ILOIPEC (2014) are very much harmonised with the findings of the current research which has revealed that the boys and girls working in the agriculture sector faced diverse types of problems and punishments such as mental, physical (physical may include sexual but none of the respondents pointed towards it in fear of social stigma), and verbal torture. On further probing it was revealed by some of the respondents that boys and girls work in fields and are often isolated for long hours without anyone for help. That is why they are prone to face the risk of violence mentioned above from their owner and co-workers. Khan et al. (2013) revealed that the children who work in farms usually use ladders, knives, hoes and other tools, as well as heavy machinery like threshers, tractors, fodder-cut machines, and operate tube-wells for irrigation purposes. The children working with all these paraphernalia underwent physical harm. The most common were injuries on arms, hands, broken bones, feet, cuts, and ankles sprains. Finger injuries are very common among farm labourers.

\section{Bivariate analysis of data}

Bivariate analysis of the data involves two variables and it is used to determine the causal relationship between the variables studied in the research (Table 7).

The bivariate analysis of the data reveals that there is a strong association between the age and the problems of the child labourers $(p=0.000)$. The relationship between the variables is highly significant. But the direction of variables involved shows a negative or inverse relationship. Associations between income and problems of child labourers $(\mathrm{p}=0.000)$, between literacy and the satisfaction of the child labourers $(p=0.000)$ and between working hours and satisfaction from the working conditions $(p=0.047)$ show a strong association between the variables. The gamma statistics show inverse or negative relationship regarding the direction of the variables involved, except for the association between working hours and satisfaction from the working conditions, which is shown to be positive. From the manifestation of the results of Chi square (p-value), the hypotheses: (1) association between age and the problems of the child labourers, (2) association between the income and the problems of the child labourers, and (3) association between literacy and the satisfaction of the child labourers from the working conditions, are accepted at $5 \%$ level of significance, while the hypothesis on the association between working hours and satisfaction from working conditions shows a weak relation at 5\% level of significance.

Statistical procedure for analysis of data involving more than one type of measurement or observation is called bi-variate analysis. It may also mean solving problems where more than one dependent variable is analysed simultaneously with other variables.

The value of R-square is 0.40 . This shows that the $40 \%$ change in problem of child labour was explained by the seven variables: age, income, education, working experience, working hours, needs and level of participation in agriculture in the model. This shows that the overall model is statistically significant. The overall significance of the model can also be judged by the F-test. The F-value is 16.374 which is significant at less than $1 \%$ level of significance. This too suggests that the relationship between the variables is highly significant.

The linear multiple regression analysis has been applied to identify the relative significance of each and

Table 7: Bivariate analysis

\begin{tabular}{lccrr}
\hline Hypothesis & Chi square & df & p value & Gamma value \\
\hline Association b/t age and problems of child labourers & 21.67 & 4 & $0.000^{* *}$ & -0.307 \\
$\begin{array}{l}\text { Association } b / t \text { income and problems of child } \\
\text { labourers }\end{array}$ & 41.58 & 4 & $0.000^{* *}$ & -0.625 \\
$\begin{array}{l}\text { Association b/t literacy and the satisfaction of the } \\
\text { child labourers from the working conditions }\end{array}$ & 38.83 & 2 & $0.000^{* *}$ & -0.681 \\
$\begin{array}{l}\text { Association b/t working hours and satisfaction from } \\
\text { working conditions }\end{array}$ & 12.73 & 6 & $0.047^{*}$ & 0.290 \\
\hline
\end{tabular}

"Significant $\quad{ }^{* *}$ Highly significant 
Table 8: Results of Regression Analysis: unstandardised, standardised regression coefficient, and level of significance of the predictor variables

\begin{tabular}{lcccr}
\hline \multicolumn{4}{c}{ Model summary } \\
\hline Model & $\mathrm{R}$ & R square & $\begin{array}{c}\text { Adjusted R } \\
\text { square }\end{array}$ & $\begin{array}{r}\text { Std. error of the } \\
\text { estimate }\end{array}$ \\
\hline 1 & $0.632^{\mathrm{a}}$ & 0.400 & 0.375 & 0.66879 \\
\hline $\begin{array}{l}\text { a. Predictors: (Constant), level of participation in agriculture, monthly income, } \\
\text { education, age, working experience, how many hours do you work daily, needs }\end{array}$ \\
\hline
\end{tabular}

\begin{tabular}{lrrrrrr}
\hline \multicolumn{7}{c}{ ANOVA $^{\mathrm{a}}$} \\
\multicolumn{1}{l}{ Model } & Sum of squares & df & Mean square & F & Sig. \\
\hline 1 & Regression & 51.268 & 7 & 7.324 & 16.374 & $0.000^{\mathrm{b}}$ \\
& Residual & 76.932 & 172 & 0.447 & & \\
& Total & 128.200 & 179 & & \\
\hline
\end{tabular}

a. Dependent Variable: Problems

b. Predictors: (Constant), level of participation in agriculture, monthly income, education, age, working experience, how many hours do you work daily, needs

\begin{tabular}{|c|c|c|c|c|c|c|}
\hline \multicolumn{7}{|c|}{ Coefficients $^{\mathrm{a}}$} \\
\hline \multirow{2}{*}{ Model } & \multirow[b]{2}{*}{$\mathrm{B}$} & & & \multirow{2}{*}{$\begin{array}{r}\text { Standardised } \\
\text { Coefficients }\end{array}$} & \multirow[b]{2}{*}{$\mathrm{t}$} & \multirow[b]{2}{*}{ Sig. } \\
\hline & & Std. Error & Beta & & & \\
\hline \multirow[t]{8}{*}{1} & (Constant) & 0.767 & 1.318 & & 0.582 & 0.561 \\
\hline & Age & -0.293 & 0.094 & -0.225 & -3.119 & $0.002 * *$ \\
\hline & Monthly income & 0.272 & 0.288 & 0.217 & 0.944 & $0.346^{\mathrm{NS}}$ \\
\hline & Education & -0.380 & 0.079 & -0.406 & -4.797 & $0.000 * *$ \\
\hline & Working experience & 0.104 & 0.099 & 0.127 & 1.059 & $0.291^{\mathrm{NS}}$ \\
\hline & Working hours & 0.023 & 0.116 & 0.027 & 0.198 & $0.844^{\mathrm{NS}}$ \\
\hline & Needs & 0.712 & 0.283 & 0.582 & 2.515 & $0.013 *$ \\
\hline & Level of participation in agriculture & 0.003 & 0.011 & 0.019 & 0.274 & $0.785^{\mathrm{NS}}$ \\
\hline
\end{tabular}

a. Dependent Variable: Problems 
every independent variable in predicting the dependent variable, i.e. the implications on family development. The regression coefficient (beta) is used to know the importance of independent variable in explaining the response variable. A higher value of (beta) of independent variable is the reflection of the importance of that variable in explaining the dependent variable. The regression coefficient is basically the rate of change in independent variable, when independent variable is changed by one unit.

\section{CONCLUSION AND RECOMMENDATIONS}

This research study concluded that child labour in the agricultural sector of Punjab, Pakistan is a reality. The children are forced to work not only to support themselves but their respective families too. There are numerous reasons which have been identified during the course of the study such as poverty, illiteracy, lack of opportunities, family profession, personal interest on the part of the respondent, tenancy, feudalism in the lower Punjab and many more. It is a grave concern of the society that in spite of the presence of effective legislation, child labour, not only in the agriculture sector but in the industrial sector also, is going on. The children are beaten, abused, mentally tortured, underpaid, sexually abused/harassed, forced to work without any time limit, and are not provided with the safety precautions. The child labourers most of the time are at the mercy of their employers and if they complaint against their employers' injustice, they are not listened to by their families, fearing of losing the economic support the children are rendering to their families. The role of the law enforcement agencies in mitigating child labour from the society is not satisfactory to a great extent. The poverty alleviation programs have failed to ensure sustenance to the rural as well urban poor families to provide a safe living to their children.

The study concluded that irrespective of the fact that the government of Pakistan is working to uplift the children of the rural areas, the trend of child labour is rising gradually due to the poor economic conditions of the rural families. As long as the economic condition of the rural people is not strengthened, the children will continue to work in the agricultural sector as child labourers and they will continue to be exploited by feudal lords in the rural areas and industrialists in the urban settlements. This research study highly recommends that, subsidies should be provided to the poor families prone to have working children, so they can afford their children's schooling (income subsidies, nutritional supplements etc.) Practical enforcement of laws framed to protect the children from working in the agricultural as well as industrial sector must be put into strict practice. Particularly the owners of the brick kilns, feudal lords and industrialists must be bound to educate the child labourers if it is not possible to avoid employing them in utmost circumstances. It has been found during the research that the poor families have more children and most of these families are unable to economically support them.

It is highly recommended that the ongoing family planning must be made more efficient. The rural communities must be convinced about the adaptation of contraceptive measures and the importance of the value of small families. The working hours of the labourers must be regularised, and the wages of the child labourers should be equal to that of adult labourers. The working atmospheres must be improved with better hygienic and sanitary conditions. Working conditions and work premises where child workers are engaged need to be improved. The trend of harassment (physical and sexual) among the child labourers must be checked with strict law enforcement. Exemplary punishments should be granted to those who violate the Acts passed by the government. The cottage industry should be restarted in the rural areas with full zeal and zest, so that the nonagricultural rural population can get themselves engaged in productive work to supplement their income during the off season. If complete eradication of child labour is not possible, it is to be made compulsory for the employers to take the responsibility to educate the children working under them by employing teachers at their farms and in the industries.

\section{CONFLICT OF INTEREST}

It is hereby declared by the authors that there is no potential conflict of interest with respect to research, financial relationship, authorship, and/or publication of this article.

\section{FUNDING}

It is hereby declared by all the authors that no funding was received from any organisation for the accomplishment of this research study.

\section{END NOTES}

1 Sometimes the child labourers support the educational expenses of their brothers and sisters, sacrificing their future and career for the family.

2 The underground water in the study area was not suitable for drinking purposes. The poor people who could not afford the water filters used to buy water from the filtration plants at high price.

3 Munshi is the person who keeps complete record of the agricultural farm. 
4 Kamins are the poor people such as cobblers, blacksmiths, barbers, potters, drumbeaters, carpenters etc.

\section{REFERENCES}

Addison, T., Bhalotra, S. and Heady, C. (1997) Child labour in Pakistan and Ghana, Mimeo, University of Warwick.

Ahmed, A. U., Hill, R. V., Smith, L. C., Wiesmann, D. M. and Frankenberger, T. (2007) The world's most deprived: characteristics and causes of extreme poverty and hunger, 2020 Discussion Paper 43, Washington DC: International Food Policy Research Institute.

DOI: https://doi.org/10.2499/0896297705

Akarro, R. R. J. and Mtweve, N. A. (2011) Poverty and its association with child labor in Njombe District in Tanzania: the case of Igima Ward, Current Research Journal of Social Sciences, 3(3), pp:199-206.

Anker, R. (2000) Conceptual and research frameworks for the economics of child labour and its elimination, ILO/IPEC Working Paper.

Arnold, D. and Bowie, N. (2003) Sweatshops and respect for persons, Business Ethics Quarterly, 13(2), pp: 221-242.

DOI: https://doi.org/10.5840/beq200313215

Baland, J. M. and Robinson, J. A (2000) Is child labour inefficient?, Journal of Political Economy, 108(04), pp: 663679.

DOI: https://doi.org/10.1086/316097

Bangladesh Bureau of Statistics \& ILO (2002-2003) Report on national child labour survey in Bangladesh, Dhaka, Bangladesh: Bangladesh Bureau of Statistics.

Bass, L. E. (2004) Child labour in sub Saharan Africa, Colorado, USA: Lynne Reinner Publishers.

Basu, K. (1999) Child Labor: Cause, consequence, and cure, with remarks on international labour standards, Journal of Economic Literature, 37(3), pp: 1083-1119.

DOI: https://doi.org/10.1257/jel.37.3.1083

Basu, K. (2000) The intriguing relation between adult minimum wage and child labour, Economic Journal, 110(March), C50-C61.

DOI: https://doi.org/10.1111/1468-0297.00520

Basu, K. and Van, P. (1998) The economics of child labor, American Economic Review, 88(03), pp: 412-427.

Bhalotra, S. and Heady, C. (1998) Child labor in rural Pakistan and Ghana: myths and data, Working Paper, Bristol, UK: Department of Economics, University of Bristol.
Binder, M. and Scrogin, D (1999) Labour force participation and household work of urban school children in Mexico: characteristics and consequences, Economic Development and Cultural Change, 48(01), pp: 123-154.

DOI: https://doi.org/10.1086/452449

Canagarajah, S. and Nielsen, H. S. (2001) Child labour in Africa: a comparative study, The Annals of the American Academy of Political Social Science, 575(01), pp: 71-91.

DOI: https://doi.org/10.1177/0002716201575001005

Castillo, L. L. \& Salem, D. S. (2016) Does globalization contribute to decreasing child labour rates?, Revistade economía mundia, 44, 127-152.

Cigno, A., Rosati, F. C. and Guarcello, L. (2002) Does globalization increase child labour?, World Development, 30(9), pp: 1579-1589.

DOI: https://doi.org/10.1016/s0305-750x(02)00053-0

Cochrane, S., Kozel, V. and Alderman, H. (1990) Household consequences of high fertility in Pakistan, World Bank Discussion Paper III, Washington, DC: World Bank.

Cohen, G. (1978) Karl Marx's Theory of History: a defense, Princeton: Princeton University Press.

Crowley, L. and Johnson, M. (2004) Hazardous child labor, Iowa City: University of Iowa Center for Human Rights [Online] Available from: http://www.scribd.com/ doc/52117657/Hazardous-Child-Labor-Crowley-and-Johnson [Accessed: 08 ${ }^{\text {th }}$ December 2010].

Dagdemir, O. and Acaroglu, H. (2010) The effects of globalization on child labor in developing countries, Business \& Economic Horizons (BEH), 2(2), pp: 37-47.

DOI: https://doi.org/10.15208/beh.2010.15

DeGraff, D. S., Bilsborrow, R. E. and Herriman, A. N. (1993) The implications of high fertility for children's time use in the Philippines, In Lloyd, C. B. (ed) Fertility, Family, Size, and Structure: Consequences for Families and Children, New York: Population Council.

Dessy, S. E. (2000) A defense of compulsory measures against child labor, Journal of Development Economics, 62(1), pp: 261-275.

DOI: https://doi.org/10.1016/s0304-3878(00)00083-3

Dessy, S. E. and Pallage, S. (2005) A theory of the worst forms of child labour, The Economic Journal, 115(500), 68-87.

DOI: https://doi.org/10.1111/j.1468-0297.2004.00960.x

Diallo, Y., Etienne, A. and Mehran, F. (2013) Global child labor trends 2008 to 2012, Geneva: ILO International Programme on the Elimination of Child Labour (IPEC) [Online] Available from:http://www.ilo.org/ipecinfo/product/download. do?type $=$ document\&id=23015 [Accessed: $25^{\text {th }}$ March 2019]. 
Emerson, P. M. and De Souza, A. P. (2000) Is there a child labour trap? Intergenerational persistence of child labor in Brazil, mimeo, NewYork: Cornell University.

Emerson, P. M. and De Souza, A. P. (2003) Is there a child labour trap? Intergenerational persistence of child labour trap in Brazil, Economic Development and Cultural Change, 51(2), pp: $375-397$.

DOI: https://doi.org/10.1086/346003

Ersado, L. (2005) Child labour and schooling decision in urban and rural areas: Comparative evidence from Nepal, Peru and Zimbabwe, World Development, 33(3), pp: 455-480.

DOI: https://doi.org/10.1016/j.worlddev.2004.09.009

Etim, N. A. and Udofia, U. S. (2013) Analysis of poverty among subsistence waterleaf producers in the tropic: implications for household food and nutrition security, American Journal of Advanced Agricultural Research, 1(2), pp: 62-68.

Etim, N. A., Edet, G. E. and Esu, B. B. (2009) Determinants of poverty among peri-urban Telferia occidentalis farmers in Uyo, Nigeria, Journal of Agriculture and Social Sciences, 5(1/2), pp: 49-51.

Faria, C. F. (2010) Why is child labour detrimental for children?, Nurture, (9), 18-21.

Ferguson, B. and Steiner, H. (2016) Exploitation, In Olsaretti, S. (ed.) The Oxford Handbook of Distributive Justice (2018) Oxford: Oxford University Press.

DOI:https://doi.org/10.1093/oxfordhb/9780199645121.013.21

Food and Agriculture Organization (2015) Handbook for monitoring and evaluation of child labour in agriculture. Measuring the impacts of agricultural and food security programs on child labor in family-based agriculture, Rome: FAO [Online] Available from: http://www.fao.org/3/a-i4630e. pdf [Accessed: 27 $7^{\text {th }}$ March 2019].

Fyfe, A. (2004) Child labour policy option, In Kristoffel, L. and White, B. (eds) Child labour and education, Revisiting the policy debate, Amsterdam: Aksant Academic Publishers.

Goodin, R. (1987) Exploiting a Situation and Exploiting a Person, Modern Theories of Exploitation, pp: 171-178.

Grier, B. (2004) Child labour and Africanist scholarship: a critical overview, African Studies Review, 47(02), pp: 1-25.

DOI: https://doi.org/10.1017/s0002020600030833

Grootaert, C. (1998) Child labour in Cote d'Ivoire: incidence and determinants, Policy Research Working Paper 1905, Washington DC: The World Bank.

Grootaert, C. and Patrinos, H. A. (eds) (1999) The policy analysis of child labor: a comparative study, London: Macmillan.
Human Rights Watch (2002) Backgrounder: child labour in agriculture, HWR World Report 2002: Children's Rights, [Online] Available from: http://hrw.org/backgrounder/crp/ back0610.htm [Accessed: $8^{\text {th }}$ May 2011].

International Labour Organization (2008) Sub-regional information system on child labour, IPEC [Online] Available from: http:/www.ilo.org/public/english/region/asro/newdelhi/ ipec/responses/pakistan/index.htm [Accessed: 03 ${ }^{\text {rd }}$ June 2008].

International Labour Organization (2015) Child labour in agriculture [Online] Available from: https://www.ilo.org/ipec/ areas/Agriculture/lang--en/index.htm [Accessed: 26 ${ }^{\text {th }}$ March 2019].

International Labour Organization (2005) Training resource pack on the elimination of hazardous child labour in agriculture Book 1: A trainer's guidebook, Geneva: International Labour Office [Online] Available from: https://www.ilo.org/ipec/ Informationresources/WCMS_IPEC_PUB_1759/lang--en/ index.htm [Accessed: $27^{\text {th }}$ November 2019 ].

International Labour Organization (2006a) The end of child labor: within reach. Global Report under follow-up to the ILO Declaration on Fundamental Principles and Rights at Work, Geneva: International Labour Office.

DOI: https://doi.org/10.7202/000146ar

International Labour Organization (2006b) Report of the Director-General: Realizing decent work in Asia, Fourteenth Asian Regional Meeting Busan, Republic of Korea, Geneva: International Labor Office.

International Labour Organization (2010) Accelerating action against child labor: Global Report under the follow-up to the ILO Declaration on Fundamental Principles and Rights at Work, p. 98, Geneva: International Labour Office.

DOI: https://doi.org/10.7202/000146ar

International Labour Organization (2013) Marking progress against child labour: global estimates and trends 2000-2012, Geneva: International Labour Office [Online] Available from: https:/www.ilo.org/wcmsp5/groups/public/---ed_norm/--ipec/documents/publication/wcms_221513.pdf [Accessed: $09^{\text {th }}$ March 2015].

International Labour Organization- IPEC (2011) Children in hazardous work. What we know. What we need to do [Online] Available from: https:/www.ilo.org/ipec/Informationresources/ WCMS 156475/lang--en/index.htm [Accessed: 09 ${ }^{\text {th }}$ March 2015]

International Labour Organization- IPEC (2014) Child labour and education: progress, challenges and future directions, Geneva: International Labour Office.

International Labour Organization- IPEC (2013) IPEC action against child labour 2012-2013: Progress and future priorities, Geneva: International Labour Office. 
Jafarey, S. \& Lahiri, S. (2001) Child labour, World Economics Journal, 2(1), pp: 69-93.

Kazmi, S. M. A. (2015) How does socio-economic factors force children into child labour? A case study of Sahiwal district, Punjab, Pakistan, Islamabad, Pakistan: Sustainable Development Policy Institute.

Kempadoo, K. (ed.) (1999) Sun, sex, and gold: Tourism and sex work in the Caribbean, p. 26, Lanham, MD: Rowman \& Littlefield.

Khan, A., Sayeed, A., Shaikh, S., Jamal, A. \& Kamran, S. (2013) Child protection system mapping and assessment 2013Punjab, Collective for Social Science Research, UNICEF: Islamabad.

Khan, R. (2014) Child labour. (A. Naz, Interviewer) Bajaur.

Kis-Katos, K. \& Gunther, S. (2005) Regulation of child labor, Economic Affairs, 25(03), pp: 24-30.

Krueger, D. \& Donohue, J. (2005) On the distributional consequences of child labour legislation, International Economic Review, 46(3), pp: 785-815.

DOI: https://doi.org/10.1111/j.1468-2354.2005.00346.x

Lana O. (2014) Child labour; the effect on child, causes and remedies to the revolving menace, LUP Student Papers, Lund, Sweden: Lund University.

Lee, D. \& Jackson, M. (2017) The simultaneous effects of socioeconomic disadvantage and child health on children's cognitive development, Demography, 54(5), pp: 1845-1871.

DOI: https://doi.org/10.1007/s13524-017-0605-z

Levison, D., Moe, K. S. and Knaul, F. M. (2001) Youth education and work in Mexico, World Development, 29 (1), pp: 167-188.

DOI: https://doi.org/10.1016/s0305-750x(00)00090-5

Maitra, P. \& Ray, R. (2002) The joint estimation of child participation in schooling and employment: comparative evidence from three continents, Oxford Development Studies, 30(1), pp: 41-62.

DOI: https://doi.org/10.1080/136008101200114895

Marx, K. (1847) Wage Labour and Capital, New York: New York Labour News Company.

Mendelievich, E. (1979) Child at work, Geneva: International Labour Organization.

Moehling, C. (1999) State child labour laws and the decline of child labour, Explorations in Economic History, 36(01), pp: 72-106.

DOI: https://doi.org/10.1006/exeh.1998.0712

Muhammad, S. (1993) Determinants of children's work and schooling in Indonesia, Ph. D. The Florida State University.
Mukhopadhyay, S. K. (1994) Adapting household behavior to agricultural technology in west Bengal, India: Wage Labour, Fertility, and Child Schooling Determinants, Economic Development and Cultural Change, 43(01), pp: 91-115.

DOI: https://doi.org/10.1086/452137

Mullings, B. (1999) Globalization, tourism and the international sex trade, In K. Kempadoo (Ed.) Sun, Sex, and Gold: Tourism and Sex Work in the Caribbean, pp: 55-80, Lanham, MD and Oxford: Rowman and Littlefield Publishers.

Narayan, D. (2000) Voices of the poor: can anyone hear us?, Oxford: Oxford University Press for The World Bank.

Nardinelli, C. (1990) Child Labour and the Industrial Revolution, Bloomington: Indiana University Press.

Nasrullah, S., Khan, M. S., Saif, N., Javed, A., Rehman, K. and Khan, H. (2013) Child labours still a hurdle in country development, Public Policy and Administration Research, 3(5), pp: 80-95.

Okunmadewa, F. (2001) Poverty reduction in Nigeria: a fourpoint demand, An Annual Guest Lecture, Ibadan, Nigeria: 'The House', University of Ibadan.

Ortiz-Ospina, E. and Roser, M. (2016) Child labour [Online] Available from: https://ourworldindata.org/child-labor [Accessed: $11^{\text {th }}$ April 2017].

Pakistan, Ministry of Labour, Manpower and Overseas Pakistanis, ILO \& IPEC (1996) Summary Results of Child Labour Survey in Pakistan.

Pakistan, National Rural Support Programme (n. d.) Child labour in cotton seed farming, a rapid assessment in district Bahawalpur, Bahawalnagar, Rahim Yar Khan and Rajanpur, Islamabad, Pakistan: National Rural Support Programme [Online] Available from: http://www.nrsp.org.pk/publications/ Baseline-Studies/Child-Labour-in-Cotton-Seed-FarmingPunjab.pdf [Accessed: 23 ${ }^{\text {rd }}$ November 2018].

Patrinos, H. A. \& Psacharopoulos, G. (1997) Family size, schooling and child labor in Peru-An empirical analysis, Journal of Population Economics, 10(04), pp: 387-405.

DOI: https://doi.org/10.1007/s001480050050

Pinstrup-Andersen, P. and Pandya-Lorch, R. (2001) Agricultural growth is the key to poverty alleviation in lowincome developing countries, The Unfinished Agenda.

Powell, B. and Zwolinski, M. (2012) The ethical and economic case against sweatshop labour: a critical assessment, Journal of Business Ethics, 107(04), pp: 449-472.

DOI: https://doi.org/10.1007/s10551-011-1058-8

Rajan, P. (2001) Credit constraint and the phenomenon of child labour, Journal of Development Economics, 64(01), pp: 81102. 
Ranjan, P. (1999) Credit constraints and the phenomenon of child labour, Working Paper 98-99-12, Irvine: University of California.

Ray, R. (2000) Analysis of child labour in Peru and Pakistan: a comparative study, Journal of Population Economics, 13(01), pp: 3-19.

Ray, R. (2002) The determinants of child labour and child schooling in Ghana, Journal of African Economies, 11(04), pp: 561-590.

DOI: https://doi.org/10.1093/jae/11.4.561

Reeve, A. (ed.) (1987) Modern Theories of Exploitation, SAGE Modern Politics series (Book 14) $1^{\text {st }}$ Edition, California, USA: SAGE Publications.

Rialp, V. (1993) Children and hazardous work in the Philippines, Geneva: International Labor Office.

Rogers, C. A. \& Swinnerton, K. A. (2008) A theory of exploitative child labour, Oxford Economic Papers, 60(1), pp: 20-41.

DOI: https://doi.org/10.1093/oep/gpm019

Sample, R. (2003) Exploitation, What It Is and Why it is Wrong, Lanham, MD, USA: Rowman and Littlefield.

Sharif, M. (1994) Child participation, nature of work, and fertility demand: a theoretical analysis, The Indian Economic Journal, 40(04), pp: 30-48.

Silvers, J. (1996) Child labour in Pakistan, The Atlantic [Online] Available from: https://www.theatlantic.com/magazine/ archive/1996/02/child-labor-in-pakistan/304660/ [Accessed: $25^{\text {th }}$ June 2019].

Simler, K. R., Mukherjee, S., Dava, G. L. and Datt, G. (2004) Rebuilding after war: micro-level determinants of poverty reduction in Mozambique, IFPRI Research Report 132, Washington, DC: International Food Policy Research Institute. DOI: https://doi.org/10.2499/0896291359rr132
Steiner, H. (1984) A Liberal Theory of Exploitation, Ethics, 94(02)pp: 225-241.

Steiner, H. (1987) Exploitation: A Liberal Theory Amended, Defended and Extended, In Reeve, A. (ed) Modern Theories of Exploitation, pp: 132-148, California, USA: SAGE Publications.

Steiner, H. (2013) Liberalism, Neutrality, and Exploitation, Politics, Philosophy \& Economics, 12(04), pp: 335-344.

DOI: https://doi.org/10.1177/1470594x13496065

Takkar, I. (2018) Article 25-A should be implemented to curb child labour, says expert, Pakistan Today [Online] 11th June, Available from:https://www.pakistantoday.com.pk/2018/06/11/ article-25-a-should-be-implemented-to-curb-child-laboursays-expert/ [Accessed: $27^{\text {th }}$ June 2019].

Togunde, D. and Carter, A. (2006) Socio-economic causes of child labour in urban Nigeria, Journal of Children \& Poverty, 12(01), pp: 73-89.

DOI: https://doi.org/10.1080/10796120500502201

Togunde, D. and Richardson, S. (2006) Household size and composition as correlates of child labour in urban Nigeria, Africa Development, 31 (01), pp: 50-65.

DOI: https://doi.org/10.4314/ad.v31i1.22250

Togunde, D. and Weber, E. (2007) Parents' views, children's voices: intergenerational analysis of child labour persistence in urban Nigeria, International Journal of Sociology of the Family, 33(2), pp: 285-301.

United Republic of Tanzania, National Bureau of Statistics (2007) Household Budget Survey (HBS).

White, B. N. F. (1996) Globalization and the child labour problem, ISS Working Paper Series/General Series, 221, pp: $1-14$.

Zwolinski, M. (2012) Structural Exploitation, Social Philosophy and Policy, 29(1), pp: 154-179. 